Article

\title{
Tax treaties between Slovakia and the Middle East countries
}

\author{
Tomas Cibula ${ }^{1}$, Matej Kacaljak ${ }^{2}$, and Peter Rakovsky ${ }^{3}$ \\ 1 Comenius University in Bratislava, Faculty of Law; tomas.cibula@flaw.uniba.sk, ORCID ID: 0000-0002-8796- \\ 4683 \\ 2 Comenius University in Bratislava, Faculty of Law; matej.kacaljak@flaw.uniba.sk, ORCID ID: 0000-0002- \\ 0289-1885 \\ 3 Comenius University in Bratislava, Faculty of Law; peter.rakovsky@flaw.uniba.sk, ORCID ID: 0000-0002- \\ 5726-3552
}

Received: 5 January 2021; Accepted: 23 January 2021; Published: 30 January 2021

\begin{abstract}
The objective of this article is to provide a basic systematic review of tax treaties between Slovakia and the Middle East States and their similarities and differences as compared to the standard OECD/UN Model Tax Conventions. The methods used include abstraction, comparison, analysis, synthesis, induction, deduction, and summarization. Findings include diverging practice concerning the scope and objective of double tax treaties such as criteria for residency, zakat provisions, transfer pricing rules, and anti-abuse rules. Taking into account the context of Slovak administrative practice and lack of experience with double tax treaties this diverging practice may lead to occasions of tax treaty override.
\end{abstract}

Keywords: double tax treaty, income tax, capital tax, zakat, anti-abuse rules, transfer pricing, caselaw

\section{JEL codes: K34}

\section{Introduction and Literature Review}

Until relatively recently, the Slovak Republic had no tax treaties with the Middle East States. However, in the last decade, four new tax treaties came into force, namely with Syria (effective from 2010), Kuwait (effective from 2014), United Arab Emirates (effective from 2017), and Iran (effective from 2018). Generally, the volume of foreign trade in goods between Slovakia and the Middle East States is relatively low with only two of the mentioned states being reflected in the Slovak statistics, namely Kuwait and the United Arab Emirates in both cases with both imports and exports reaching negligible rates of total volumes reported in the Slovak Republic.

Table 1. Imports and Exports to/from Slovakia from/to Kuwait and the United Arab Emirates (kEUR and \% of total)

\begin{tabular}{cccccccc}
\hline & & $\mathbf{2 0 1 8}$ & $\mathbf{2 0 1 7}$ & $\mathbf{2 0 1 6}$ & $\mathbf{2 0 1 5}$ & $\mathbf{2 0 1 4}$ & $\mathbf{2 0 1 3}$ \\
\hline \multirow{3}{*}{ TOTAL } & Import c.p. & 76835039 & 70778213 & 66187593 & 64447000 & 59792783 & 59560590 \\
\cline { 2 - 8 } & Export c.p. & 79144529 & 73851898 & 69554586 & 67606968 & 64565418 & 64131460 \\
\hline & Import c.p. & 536 & 288 & 169 & 162 & 38 & 183 \\
\cline { 2 - 8 } Kuwait & Export c.p. & 121025 & 73056 & 53642 & 65230 & 54529 & 54286 \\
\cline { 2 - 8 } & Import \% total & $0,001 \%$ & $0,000 \%$ & $0,000 \%$ & $0,000 \%$ & $0,000 \%$ & $0,000 \%$ \\
\cline { 2 - 8 } & Export \% total & $0,153 \%$ & $0,099 \%$ & $0,077 \%$ & $0,096 \%$ & $0,084 \%$ & $0,085 \%$ \\
\hline & Import c.p. & 26109 & 15596 & 11199 & 10223 & 5431 & 1932 \\
\cline { 2 - 8 } & Export c.p. & 144126 & 180827 & 163005 & 178441 & 152068 & 148258 \\
\cline { 2 - 8 } United Arab Emirates & Import \% total & $0,034 \%$ & $0,022 \%$ & $0,017 \%$ & $0,016 \%$ & $0,009 \%$ & $0,003 \%$ \\
\cline { 2 - 8 } & Export \% total & $0,182 \%$ & $0,245 \%$ & $0,234 \%$ & $0,264 \%$ & $0,236 \%$ & $0,231 \%$ \\
\hline
\end{tabular}

Source: Statistics Office of the Slovak Republic - DataCube Database (2020) 
The primary export goods from Slovakia were automobiles due to several automobile production plants being based in Slovakia (VW, PSA, KIA) and fluctuations in the export values are mostly due to production programs of these plants (Slovak Ministry of Foreign Affairs, 2020). As to the imports, the total values for Kuwait are less than one million EUR, therefore any fluctuations (however significant the yearly changes may seem) might have been affected by a single transaction and it is difficult to infer any generalizations. For the United Arab Emirates, the commodity structure comprises tin alloy, electrical machinery, motor vehicles, and nuclear reactors. (Slovak Ministry of Foreign Affairs, 2020) There seems to be a clear increasing trend correlating with the intensification of mutual diplomatic relations and entering into several bilateral treaties; e.g. the tax treaty became effective in 2017, bilateral investment treaty in 2018. (Slovak Ministry of Foreign Affairs, 2020)

Similar volumes are shown in the foreign direct investments statistics with only one country being shown in the statistics, namely the United Arab Emirates, and the number of capital inflows to Slovakia being approx. 5 million EUR in 2018 and approx. 1 million EUR in the preceding years (NBS, 2020).

The tax treaties, particularly the tax treaty with the United Arab Emirates, may provide for a potential increase of the above values, though at the moment it is difficult to observe any significant correlations due to the treaties with the United Arab Emirates and Iran becoming relatively recently (i.e. years 2017 and 2018 respectively) and statistics for 2019 not being available yet.

Nevertheless, a more robust analysis would seem pertinent to assess the overall impact of bilateral tax treaties and/or bilateral investment treaties on the mutual trade of the analyzed countries. Up to now, this topic has not been covered in literature, though general policy considerations have been discussed from a historical perspective. (Kubicová \& Holczerová, 2012; Kubicová, 2012) It would be possible to employ the methodology of Braun \& Fuentes (2016) and Barthel et al. (2010) and though it is out of the scope of this paper it seems a promising area for future research.

In any case, from a legal perspective, the structure of the treaties is equally important as their very existence and therefore it seems reasonable to analyze these in the light of certain pre-selected criteria.

The objective of this paper is to provide a summary of the main features of the above tax treaties, particularly in the light of the OECD/UN Model Tax Conventions, recent academic literature, and caselaw of Slovak courts, and practice of Slovak Tax Authorities.

Further, the objective of this paper is to discuss the interrelation, through these tax treaties, between the Slovak tax system (with its tax mix traditionally focusing on income and consumption taxation) (Výškrabka \& Antalicová, 2018) and the tax systems of the respective Middle East States, where some contain elements not known to the Slovak tax system, e.g. the Zakat element in Kuwait (Deloitte, 2019).

The academic literature to date has discussed rather extensively the OECD/UN Model Tax Conventions, their interpretation over the world, and certain diverging practices (Becker \& Reimer \& Rust, 2015); (Engelen, 2004); (Garbarino, 2016). However, little to no focus was given to Slovak tax treaties or Slovak tax treaties with the Middle East States.

The legal nature of Zakat was already discussed in academic literature (Allami, 2016) but discussions of tax treaty implications are rare.

\section{Methods}

Based on a geographic criterion (Middle East) and religious influence on the state constitution (Islam) the list of four double tax treaties with Syria (Collection of Laws of the Slovak Republic, No. 35/2010), Kuwait (Collection of Laws of the Slovak Republic, No. 93/2014), United Arab Emirates (Collection of Laws of the Slovak Republic, No. 58/2017) and Iran (Collection of Laws of the Slovak Republic, No. 122/2018) was first compiled from the entire list of effective double tax treaties binding on the Slovak Republic.1

As of the date of the compilation of the list of treaties to be analyzed and there were seventy double tax treaties effective and binding on the Slovak Republic. As was already stated above, the 
economic impact of existing tax treaties on the Slovak economy has not been evaluated in the literature and shows a promising area for future research.

Secondly, any existing protocols or other amendments to the analyzed treaties were taken into account with the Multilateral Convention to Implement Tax Treaty Related Measures to Prevent Base Erosion and Profit Shifting ("MLI") being effectively the only international law instrument modifying the analyzed treaties.

Thereafter, the text of the tax treaties was analyzed through doctrinal and legal analysis. The methods used include the method of abstraction, comparison, analysis, synthesis, induction, deduction, and summarization. As a starting point for the comparison, the OECD (OECD,2019) and the UN (UN, 2017) Model Tax Conventions were consulted to identify any diverging practice.

To avoid unnecessary fragmentation, the analysis of the tax treaties was narrowed down to the following topics:

- The substantive scope of the double tax treaties, i.e., the taxes covered.

- Personal scope, i.e., the definition of a resident of a contracting state.

- Definition of permanent establishment.

- $\quad$ Passive income provisions, i.e., the dividends, interest, and royalties' provisions.

- Transfer pricing rules and anti-abuse provisions.

- Impact of MLI, i.e., if and how the analyzed treaty was affected by the changes introduced by MLI.

Through the method of abstraction, the common features in the tax treaties were identified. The feature that was present in the majority of the treaties was labeled as a standard.

After we have identified the common (standard) features, thorough method of comparison we have identified features that either deviated from the standard, and subsequently we have identified features that deviate from the Model Tax Conventions.

Finally, we have performed a textual and contextual analysis of the identified features and through methods of induction and deduction, we have tried to formulate more general observations. of :

In addition to the above analysis, the analyzed tax treaties were assessed against the background

- tax treaty case-law of Slovak courts with particular emphasis on recent case-law of Slovak courts on the topic of tax treaty abuse.

- application of OECD/UN Commentaries and OECD Transfer Pricing Guidelines as interpretation tools of tax treaties in Slovak court practice.

- possibility of tax treaty overrides under Slovak Constitutional Rules.

The above topics are relevant to the tax treaty practice in general and may provide lighter also on potential issues arising from the implementation of agreements divergent from the OECD/UN Model Tax Conventions.

\section{Analysis and Results}

The results of the analysis are discussed below in separate subsections in line with the aboveindicated topics. Generally, the structure of the analyzed tax treaties conforms to one of the OECD/UN Model Tax Conventions, which enables their further detailed analysis.

Where the wording of the analyzed tax treaty in the respective article corresponds to the OECD or UN Model Tax Convention in its entirety, it is concluded that a standard wording is used. If there was any divergence identified, this will be described in greater detail. 


\subsection{Substantive Scope}

The scope of all four analyzed double tax treaties is limited only to taxes on income, i.e. capital taxes are excluded. Concerning the definition of taxes on income the standard wording used by Article 2 of the OECD Model Tax Convention is used covering taxes "imposed on behalf of a Contracting State or of its political subdivisions or local authorities, irrespective of how they are levied".

This is followed by a wording identical to Article 2(2) and a list of taxes levied in each contracting state.

In addition to the exclusion of taxes on capital, the double tax treaty with the United Arab Emirates further narrows down its scope by stating in its Article 5 that the treaty does not affect the "domestic laws and regulations related to the taxation of income and profits derived from hydrocarbons and its associated products situated in the territory of the respective Contracting State, as the case may be."

The treaty with Kuwait expressly lists in Article 2(3)a)4. the "zakat" as one of the taxes covered by the treaty. Without going into a detailed discussion of the nature of the particular Zakat tax in Kuwait2, by expressly including this tax in the list of covered taxes it is assumed that this tax falls under the treaty scope even if it would not fall under the definition of tax on income (Becker \& Reimer \& Rust, 2015).

\subsection{Personal Scope}

Though all the analyzed treaties state in their Article 1 that they apply to persons being residents in one or both of the contracting states, the criteria for residency in Articles differ between the treaties.

While the treaty with Syria and Iran employ the standard wording used in the OECD/UN Model Tax Conventions, the two remaining analyzed treaties take a slightly different approach.

Firstly, Kuwait uses the standard wording only concerning legal entities and Slovak individuals while for Kuwait individuals it expressly states that an individual is deemed a resident of Kuwait if he has a permanent residence in Kuwait AND is a national of Kuwait.

The tax treaty with the United Arab Emirates diverges entirely from the use of standard language used in Article 4(1) of the OECD Model Tax Convention for residents of the United Arab Emirates (this standard language is used only concerning residents of Slovakia) and rather contains a list of specific subjects being deemed residents of United Arab Emirates.

In particular, concerning business companies, their residency test in Article 4(1)(a)(iv) is based on their being established under the laws of the United Arab Emirates. This effectively means that under the treaty no residency conflict may arise if a company established under the laws of the Slovak Republic has its place of effective management in the United Arab Emirates. Even if the United Arab Emirates (or any of the Emirates) would employ a place of effective management criterion as a tax residency test for business companies, under the tax treaty this test will be disregarded and the company would remain a Slovak tax resident. ${ }^{3}$

\subsection{Definition Of Permanent Establishment}

The definitions of a permanent establishment in Articles 5 of the analyzed treaties (Article 6 in case of the tax treaty with the United Arab Emirates) essentially conform to the standard wording used in the OECD Model Tax Convention with deviations relating to the construction site concept and the services permanent establishment concept which both conform to the reservations made by the Slovak Republic to Article 5 of the OECD Model Tax Convention (OECD, 2017). These correspond to Slovak standard practice which is based on the UN Model Tax Convention (Kubicová \& Holcerová, 2012).

\footnotetext{
${ }^{2}$ As was already indicated above, the features of this particular tax seem to be more in line with a tax on income than of tax on capital.

${ }^{3}$ Based on publicly available information this situation seems hypothetical for now.
} 
From the Slovak perspective and the recent discussions on taxation of the digital economy (Olbert \& Spengel, 2017; ) this is relevant as Slovakia was one of the jurisdictions employing a unilateral measure attempting to tax profits generated by the digital platform. This was attempted through a "digital platform permanent establishment" concept and the publicly declared ambition of the Slovak legislator was to effectively override the respective tax treaty through the renvoi concept in Article 3(2) of the respective tax treaty. This was criticized in Slovak academic literature (Cibula \& Kačaljak, 2018). Nevertheless, the available data on tax yield shows that the concept was ignored by the foreign taxpayers conducting business in Slovakia through digital platforms, e.g. Booking, Airbnb (Financial Directorate of the Slovak Republic,2020).

Given the conformity of the permanent establishment definitions in the analyzed treaties, it might be argued that the Slovak digital platform permanent establishment concept will not be effective either concerning digital platform operators resident in Syria, Kuwait, United Arab Emirates, or Iran.

\subsection{Passive Incomes}

The wordings of Articles 10, 11, 12 (11,12, 13 for the tax treaty with the United Arab Emirates) essentially conform to the OECD Model Tax Convention.

The rates of tax that may be imposed on the passive incomes in the source state are as follows:

Table 2. Applicable Rates in The Source State

\begin{tabular}{cccc}
\hline State / Rate & Dividends & Interest & Royalties \\
\hline Syria & $5 \%$ & $10 \%$ & $12 \%$ \\
\hline Kuwait & $0 \%$ & $10 \%$ & $10 \%$ \\
\hline United Arab Emirates & $0 \%$ & $10 \%$ & $10 \%$ \\
\hline Iran & $5 \%$ & $5 \%$ & $7.5 \%$ \\
\hline
\end{tabular}

Besides, the treaties with Kuwait and the United Arab Emirates contain rather extensive lists of recipients concerning which the interest and royalties should be paid out without any tax imposed at the source.

\subsection{Transfer Pricing Rules and Anti-Abuse Provisions}

Transfer pricing rules in all the analyzed treaties are construed in wordings corresponding to those used in the OECD/UN Model Tax Conventions with some minor divergences.

The treaty with Iran contains general anti-abuse provisions either in the form of a sui generis principal purpose test in Article 26. The treaty with the United Arab Emirates contains a limitation on the benefits clause in Article 27.

\subsection{Impact of $M L I$}

Currently, MLI might affect only the tax treaty with Kuwait though Kuwait has not deposited the ratification instrument yet and thus the MLI is not effective for the treaty.

Syria and Iran are not signatories of MLI.

To the tax treaty with the United Arab Emirates, the Slovak Republic has not included the treaty in its covered agreement list. Nevertheless, the treaty already seems to reflect several of the features that were to be introduced by MLI into the older treaties, such as the limitation on the benefits clause.

\subsection{Idiosyncracies in Slovak Tax Treaty Practice}

In general, tax treaty disputes are relatively rare in Slovakia. A review of published judgments available in public databases ${ }^{4}$ shows only 11 decisions of the Slovak Supreme Court and $8^{5}$ decisions

\footnotetext{
4 We have worked with the database judikaty.info, which should contain a comprehensive catalog of all decisions of Slovak courts, that were made public in digital form to date.

5 Not counting the decisions which were reviewed by the Slovak Supreme Court included in the previous count.
} 
of Slovak Regional Courts related to tax treaty issues ${ }^{6}$. Moreover, several of the disputes concern the same participant and in one case one single dispute, which was already decided twice by the Slovak Supreme Court and third (potentially final) decision is currently pending, while the analysis of the Regional Court decisions ${ }^{7}$ shows a slight tendency of Regional Courts to reject the petitions (on several occasions without delivering satisfactory reasoning) ${ }^{8}$.

The ratio of decisions where the taxpayer was successful to those where the court has rejected the court petition is 13 to 6, which indicates that the Slovak Tax Authorities do not have significant expertise in handling tax treaty cases. Moreover, taking into account only Slovak Supreme Court Cases, the ratio is 9 to 2 in favor of the taxpayer.

Upon detailed analysis of the above cases, several general observations may be formulated for tax treaty interpretation in Slovakia.

Firstly, due to the monist principle with a prevalence of an international treaty being applied in the Slovak Constitution, the analyzed tax treaties are directly applicable in Slovakia and take precedence before the Slovak laws. (Kočiš, 2011) Treaty override should thus not be possible in theory, though it may not be entirely excluded that isolated occurrences of treaty override would occur due to misapplication of the treaty.

Secondly, under a relatively stabilized case-law in the Slovak Republic, the OECD/UN Commentaries could be used as interpretation tools concerning the tax treaties with the static approach being the starting point (Koroncziová \& Kacaljak, 2017). On the other hand, the relevance of OECD Transfer Pricing Guidelines, though being used and referred to rather extensively by the Slovak Tax Authorities, is rather limited by the case-law of Slovak courts and in general, they should be relied upon only as a consultation material to methodological issues (Kačaljak \& Rakovský, 2019).

Further, there has been an isolated effort of the Regional Court in Bratislava to uphold the override of tax treaty through transplantation of general anti-abuse principles from decisions of foreign courts (primarily the Court of Justice of the European Union and the Czech Supreme Administrative Court). Nevertheless, the court did not tackle the issue of whether (i) prohibition of abuse of law was a principle inherent in Slovak tax law even before the Slovak GAAR was codified with effect from 2014; neither whether (ii) such principle would be capable of overriding the tax treaty. (Kačaljak \& Koroncziová, 2018). The decision of the Slovak Supreme Court on the matter is still pending.

Thirdly, the transfer pricing is getting into the focus of Slovak Tax Authorities with the amount of assessed tax (including reduction of reported tax loss) increasing from EUR 7 million in 2016 (Financial Administration, 2017) to EUR 171 million in 2019 (Financial Administration, 2020). However, the practice of the Slovak Tax Authorities shows certain idiosyncratic elements that present a risk of (i) double taxation; and, at the same time under certain circumstances, or (ii) creating a de facto safe harbor regime. This is due to excessive reliance on the transactional net margin method without taking note of all the methodological caveats in the OECD Transfer Pricing Guidelines (Kačaljak \& Choma \& Rakovský, 2020). That said, the disputes concerning transfer pricing have only recently been dealt with Slovak courts and the decisions have been passed only by Regional Courts (on one occasion the decision was already reviewed by the Slovak Supreme Court which ruled that the reasoning was insufficient and returned the case to the Regional Court). Thus, court practice in transfer pricing disputes is only forming.

Finally, from the analysis of the available case law, it seems that the decisions that could rely on international literature and OECD/UN Commentaries might be regarded as more elaborate on one hand and less controversial on the other. We find this as a supporting argument for using standardized wordings in double tax treaties entered into by Slovakia and as few deviations as possible.

\footnotetext{
6 The list of case nos. and, where available, links to full wordings of the decisions are attached as Annex 1 hereto.

7 Including those which were reviewed by the Slovak Supreme Court.

8 This was expressly pointed out by the Slovak Supreme Court on several occasions.
} 
This section should include a description of the results and the discussion. Authors should discuss the results and interpret them in the context of earlier publications.

\section{Conclusions}

Generally, the analyzed tax treaties seem to be conforming to the OECD/UN Model Tax Convention with only minor divergences.

The diverging practice has been identified in the analyzed tax treaties, inter alia, for the objective scope, personal scope, and passive income provisions.

Though minor, these may still bring uncertainty to the practical application of the treaty.

This uncertainty is aggravated if the tax treaty practice in the given jurisdiction, such as Slovakia, is relatively rare and the taxpayers thus lack recourse to a stabilized case-law and extensive jurisprudence.

Particularly complicated concerning any jurisdiction with dominant Islamic element might be the issue of Zakat, which is unknown in the Slovak legal environment and may bring significant challenges to the Slovak taxpayers as well as the Slovak tax administrations, even though in one of the analyzed treaties it was expressly included in the covered taxes article.

To the parts of texts of the analyzed tax treaties conforming to the standards in the OECD/UN Model Tax Conventions, the taxpayers should be able to some extent rely on the commentaries to these, as these are accepted as interpretational tools with the static approach being the starting point of analysis.

The potential for future research lies in the analysis of the impact of double tax treaties (and potentially also bilateral investment treaties) on the Slovak economy, where it is possible to follow up on the work already published in the literature.

The case-law review may also be updated to include any new developments. Given the several pending cases before the Slovak Supreme Court, there may be noteworthy decisions relating to treaty abuse and transfer pricing.

Funding: The study is the part of the project no. APVV-16-0499 „Zabezpečenie efektívneho výberu daní v kontexte informatizácie" (Ensuring effective tax collection in the context of informatization).

Author Contributions: “Conceptualization, T. Cibula, M. Kačaljak, P. Rakovský; methodology, M. Kačaljak; data curation, P. Rakovský, T. Cibula; formal analysis, P. Rakovský, M. Kačaljak; writing-original draft preparation, P. Rakovský, T. Cibula; writing-review and editing, M. Kačaljak; supervision, M. Kačaljak; project administration, M. Kačaljak; funding acquisition, M. Kačaljak. All authors have read and agreed to the published version of the manuscript."

Conflicts of Interest: The authors declare no conflict of interest. The funders had no role in the design of the study; in the collection, analyses, or interpretation of data; in the writing of the manuscript, or in the decision to publish the results.

\section{References}

Allami, A. W. (2016). Principalizing Islamic Zakat as a system of taxation (Doctoral dissertation, Brunel University London).

Al Matar, F. (2011). The Role of Taxation in a Post-Oil Kuwait (Doctoral dissertation, University of Warwick).

AlMatar, F. (2015). Zakat vs. Taxation: the issue of social justice and redistribution of wealth. European Journal of Business, Economics, and Accountancy, 3(3).

Barthel, F., Busse, M., Krever, R., \& Neumayer, E. (2010). The relationship between double taxation treaties and foreign direct investment. Tax Treaties: Views from The Bridge-Building Bridges Between Law and Economics, 3-18.

Becker, J., Reimer, E., \& Rust, A. (2015). Klaus Vogel on Double Taxation Conventions. Kluwer Law International. Braun, J., \& Fuentes, D. (2016). The Effects of Double Tax Treaties for Developing Countries. A Case Study of Austria's Double Tax Treaty Network. Public Finance \& Management, 16(4). 
Cibul'a, T. \& Kačaljak, M. (2018). TAX TREATY OVERRIDE IN SLOVAKIA-DIGITAL PLATFORM PERMANENT ESTABLISHMENT. Semi-annual scholarly legal journal of Faculty of Law, Comenius University in Bratislava., 80.

Cibul'a, T., Hlinka, T., Choma, A., \& Kačaljak, M. (2019). DIGITÁLNA PLATFORMA AKO STÁLA PREVÁDZKAREŇ. Právny obzor. Teoretický časopis pre otázky štátu a práva (Juridical Review. Theoretical journal for the questions of state and law), 102(2).

The decision of the Regional Court in Bratislava No. 6S/34/2016 dated on 3rd May 2017.

Engelen, F. A. (2004). Interpretation of tax treaties under international law. 7

Financial Administration of the Slovak Republic (2016). Annual Report for the Year 2015.

Financial Administration of the Slovak Republic (2020). Annual Report for the Year 2019.

Garbarino, C. (2016). Judicial interpretation of tax treaties: the use of the OECD commentary. Edward Elgar Publishing.

Kačaljak, M., Rakovský, P. (2019) Právny charakter OECD Smernice o transferovom oceňovaní na Slovensku, Justičná revue 11/2019.

Kačaljak, M., Koroncziová, A. (2018). Zneužitie zmlúv o zamedzení dvojitého zdanenia - Slovensko. Acta Universitatis Carolinae Iuridica, 64(1).

Kočiš, M. (2011). Postavenie medzinárodných zmlúv v systéme prameňov daňového práva a ich interpretácia. Mílniky práva v stredoeurópskom priestore 2011.

Koroncziová, A., \& Kacaljak, M. (2017). Gaar As Tax Treaty Override-Slovak Perspective. DANUBE: Law and Economics Review, 8(3), 139-155.

Kubicová, J. \& Holczerová, J. (2012). Tax Treaty policy of Slovakia over the years. Second Period (From 1970 Till Now) Globalizácia a jej sociálno-ekonomické dôsledky 2012. Peer-reviewed conference proceedings, Podniková ekonomika a manažment.

Kubicova, J, (2012) Tax Treaty Policy of Slovakia Over the Years - Early Treaties and First Period (from 1867 to 1969) (September 14, 2012). Globalizácia a jej sociálno-ekonomické dôsledky 2012, Peer-reviewed conference proceedings. Podniková ekonomika a manažment

Lang, M. (2014). Introduction to the law of double taxation conventions. Linde Verlag GmbH.

Maisto, G. (Ed.). (2006). Tax treaties and domestic law .2. IBFD.

NBS. (2020). National Bank of Slovakia. Foreign Direct Investment Statistics.

Olbert, M., \& Spengel, C. (2017). International taxation in the digital economy: challenge accepted. World Tax Journal, 9(1), 3-46.

Rakovsky, P. (2018). Princíp nezávislého vztahu ako jeden zo spôsobov zabránenia zneužitiu práva v daňovej oblasti. Acta Facultatis Iuridicae Universitatis Comenianae, 37(2), 253.

Ristvej, J. (2010). Vedecké Metódy. Trilobit. Odborný vedecký časopis. Teorie. 1.

Slovak Ministry of Foreign Affairs (2020) Economic Information on Territory for Iran, Kuwait, Syria, and United Arab Emirates, respectively

Výškrabka, M., Antalicová, J. (2018). Tax Report of the Slovak Republic (Daňový report Slovenskej republiky). Institute for Fiscal Policy.

Wattel, P. J., \& Marres, O. C. R. (2003). The legal status of the OECD Commentary and static or ambulatory interpretation of tax treaties. European taxation and market anomalies. Journal of Portfolio Management, 25(2), 53-69. https://doi.org/10.3905/jpm.1999.319734

(C) 2020 by the authors. This article is an open-access article distributed under the terms and conditions of the Creative Commons Attribution (CC BY) license (http://creativecommons.org/licenses/by/4.0/). 